\title{
The false promises of the (second) Washington consensus: evidence from Latin America and the Caribbean (1990-2003)
}

\author{
ERIC BERR \\ FRAN ÇOIS COMBARNOUS*
}

The objective of this paper is twofold. Firstly, we show how, and to what extent, Latin A merican and Caribbean countries applied the precepts of the second Washington consensus, i.e. a consensus which stresses the capital account liberalization. Secondly, we highlight the effects of this set of reforms on their economies. Thus, we show that countries having most scrupulously followed these recommendations did not experience better economic results. O n the contrary, their situation as regards inequality and debt is getting worse than others.

Key-words: Washington consensus, Financial liberalization, M acroeconomic policy, International financial institutions, Latin A merica, Caribbean.

JEL Classification: 011,0 19, 0 54, E61, F42.

\section{INTRODUCTION}

Since the beginning of the debt crisis in 1982, which started with M exico's default, Latin American countries have been living in accordance with the structural adjustment programs and poverty reduction strategies initiated by the International M onetary Fund (IM F) and the World Bank. Based on the promotion of market adjustment, the reduction of the size of government and an increasing openness to foreign investment, these policies were codified by Williamson [1990] and his Washington consensus in a program that prescribed theten commandments of the neoclassical economic bible.

\footnotetext{
* GREThA, University of Bordeaux, CNRS, avenue Léon Duguit, 33608 Pessac, France. E-mail: berr@ubordeaux4.fr and combarno@u-bordeaux4.fr. Submitted: July 2006 ; accepted: N ovember 2006. Associate professors at Université M ontesquieu-Bordeaux IV, France. E-mail: berr@u-bordeaux4.fr, combarno@ubordeaux4.fr.
} 
The potion administered to Latin American and Caribbean countries by the international financial institutions (IFIs), beginning in the early 1990's, however differs from Williamson's initial recipe on two points: the definition of a competitive exchange rate and the degree of financial liberalization. For Williamson, a competitive exchange rate presupposes an intermediate regime that would be quicker to avoid an overvaluation of the national currency which would penalize exports, whereas in the 1990's IFIs were promoting extreme exchange regimes, that is to say totally fixed (as in the case of a currency board) or entirely flexible. Concerning financial liberalization, ${ }^{1}$ W illiamson expressed on numerous occasions (Williamson [2000], [2004]) his opposition to the liberalization of capital account even if he is favorable to the suppression of barriers to foreign direct investment (FDI). M ore generally, he regretted that the usage that has been made of the Washington consensus does not correspond to his initial project.

Financial liberalization is a major element of the policies championed by IFIS in the 1990's, thus giving birth to a "second" Washington consensus (BresserPereira and Varela [2004]). ${ }^{2}$ W hereas the "first" Washington consensus (of the 1980's) stressed policies of stabilization and structural reforms, the second encourages the opening of capital account in order to attract foreign savings that is supposed to favor economic growth (Bresser-Pereira [2002]).

The objective of this paper is twofold. First we wish to see how, and to what extent, Latin A merican and Caribbean countries have applied the precepts of the second Washington consensus and then highlight the effects of this set of reforms on their economies.

\section{THE APPLICATION OF THE SECOND WASHINGTON CONSEN SUS IN LATIN AMERICA AND THE CARIBBEAN}

It is widely accepted that Latin A merica and the Caribbean have been the part of the world where the liberal precepts of the second Washington consensus have been the most closely follow ed (Birdsall and de la Torre [2001], O campo [2004], Rodrik [2004], Sanchez [2003]). H owever, the multiple dimensions of the program, that we will detail in the first place, make any immediate and overall

\footnotetext{
${ }^{1}$ The process of financial liberalization is based on three fundamental aspects: (i) the liberalization of the internal financial sector which encompasses the liberalization of interest rates, loans and the competition between banks as well as the reduction, even elimination of reserve requirements; (ii) the liberalization of financial markets, that is to say the suppression of barriers to the holding of titles by foreign investors and the elimination of obstacles to the repatriation of capital and the payment of dividends, interests and profits; (iii) the opening of capital accounts, that is, the possibility for financial institutions to grant loans to foreign sources, the elimination of the control of exchanges and the liberalization of capital flow (Ben Gamra et Clévenot [2006]). It is essentially the realization of this last point that founds the second Washington consensus.
}

${ }^{2}$ A restis [2004] speaks of a "revised" Washington consensus. 
evaluation of the degree of its application impossible. Although it is relatively easy to gauge the implementation of any one of the constitutive elements of this program, it is much more difficult to obtain an empirical measurement of its application from the sum total of recommended measures. This leads us to construct an indicator measuring the level of engagement of Latin A merican and Caribbean countries in the set of liberal reforms promoted by IFIs.

What is the second Washington consensus?

The second Washington consensus appears at the beginning of the 1990's. Whereas the Brady plan seems to have solved the debt crisis and capital was again flowing toward numerous developing countries (which then became emerging countries), IFIs, after having devoted their attention in the 1980's to stabilization and structural reforms, begin to stress economic growth. But, rather than returning to indebtedness, IFIs assert that it is the attraction of foreign savings that encourages growth. This new strategy, which involves the opening of capital account, marks a second step in the implementation of the Washington consensus because it implies full-scale financial liberalization. From then on, the second Washington consensus will be composed of $10+1$ measures: $^{3}$

(1) Budgetary Austerity (BA): a balanced budget must be attained in the medium-term as significant budget deficits are the source of inflation, balance of payments crises and volatile capital. Unofficially, the return to a balanced budget aims to limit state indebtedness so that the repayment of the public internal debt does not replace that of the external public debt that must also be moderated. ${ }^{4}$

(2) Reduction of public expenditures to limit the size of government (SG): from a neoclassical perspective, the quest for a balanced budget and a reduced role of the government requires a decrease in government spending rather than an increase in fiscal pressure. Subsidies should also be reduced in order to avoid market distortion. ${ }^{5}$

(3) Promotion of an orthodox monetary policy based on the liberalization of interest rates (M P): interest rates must be market-determined and real interest rates must be positive and moderated in order to attract international capital necessary to finance development, without compromising investment and the repayment of the public debt.

(4) Promotion of exports (PEX): Although Williamson and the IFIs differ in terms of which exchange regime to adopt, they nevertheless agree that the promotion of exports is the best way to favor growth while maintaining the deficit

\footnotetext{
${ }^{3} \mathrm{~A}$ detailed and more technical definition of the variables composing our future indicator is given in Annex 1.

${ }^{4}$ W illiamson [1990] concedes that a budget deficit is acceptable in the short term if it does not represent an increase in the size of debt.

${ }^{5}$ Although Williamson [1990] thinks that the reduction of subsidies allows for the redirection of public spending toward education, health and infrastructure, IFIs will adopt a much more radical approach involving a uniform decrease in public expenditure in order to reduce the size of government.
} 
of the balance of payments on current account at a level that can be sustainably financed.

(5) Trade Liberalization (T LI): in its initial version, the Washington consensus simply envisages (in the logic of the promotion of exports) the liberalization of commercial exchange. This involves limiting, even eliminating, all tariff and nontariff barriers.

(6) Competitiveness of foreign direct investment (CO): although W illiamson does not suggest a total liberalization of capital movement, action must nevertheless be taken against the barriers that curb the entry of foreign direct investment (FDI).

(7) Privatization (PZ): there is a large consensus on this point as private firms are assumed to be better managed than public ones. Privatization also aims to hel $p$ reestablish a balanced budget and to reduce public investment, thus decreasing the size of government. ${ }^{6}$

(8) Deregulation (DE): the objective is to abolish, or if not reduce, the barriers to markets, therefore the elimination of regulations which slow economic initiative and free competition.

(9) Fiscal reform (FR): the objective is twofold. It involves an increase in the number of taxpayers by enlarging the fiscal base through a broadening of value added tax and the reduction of marginal tax rates.

(10) Property rights (PR): involves reinforcing property rights and ensuring a legal framework for the defense of private interests.

$(\mathbf{1 0 + 1 )}$ Financial liberalization (FLI): the beacon of the second Washington consensus. Whereas Williamson [1990], [2000] makes it clear that the liberalization of capital movement is not a priority, it was, however, imposed in the 1990's under the pressure of IFIs, representing the final stage of financial liberalization.

The second Washington consensus indicator (WCI)

$\mathrm{N}$ umerous studies have already highlighted the impact of certain measures of the Washington consensus on a number of variables characterizing the level of development. It is, however, much more difficult to obtain an empirical measurement for the application of the sum total of recommended measures. With this in mind, Lora [2001] constructs an index of structural reforms in order to measure the progress accomplished in five domains: trade policy, financial policy, fiscal policy, privatization and labor market reforms. Correa [2002] completes this approach by considering the possible complementary relationship between the five domains mentioned above. For our part, we wish to precisely evaluate the level of engagement of Latin A merican and Caribbean countries in

\footnotetext{
${ }^{6}$ Contrary to IFIs, Williamson believes that in certain cases (public transport or water infrastructure for example) such privatization is inappropriate. Stiglitz [2002] agrees with him on this point.
} 
the set of liberal reforms that constitute the second Washington consensus. For that purpose, we suggest implementing factor analysis. ${ }^{7}$

A mong the different methods of factor analysis, principle components analysis (PCA ) applies to crosstabs that intersect cases (countries) and quantitative variables (the different dimensions of IFI programs). The appraisal of the correlations between initial variables established by PCA is for us its most significant contribution. It allows us to reduce a set of observed variables into a smaller set of artificial variables called principle components. ${ }^{8}$ The choice of data requires particular attention and raises a certain number of difficulties. Indeed, it is important to avoid the confusion between the measurement of the objectives of recommended policies and that of the means implemented to attain them. As our aim is to judge the degree of application of policies, we have chosen to only take variables that measure the level of completion of the objectives of these policies. $\mathrm{O}$ n the other hand, it is clear that some of these objectives, like for example the state of property rights in a country, can only be apprehended a priori by qual itative variables to which the chosen technique of analysis does not apply. It was therefore necessary to find or establish eleven quantitative variables that would allow us to apprehend as best as possible each one of the dimensions of the second Washington consensus. The sources of this data as well as the technical details concerning their construction can be found in A nnex 1.

We have, for year 2003 and for 23 Latin A merican and Caribbean countries, eleven quantitative variables representing the el even essential dimensions of the policies promoted by the IFIs. The results of the PCA in this table are satisfactory with respect to our principle objective. The first three factors capture more than $60 \%$ of the total variance in the data set. Thus, the three new synthetic variables constituted from the first three factorial axes of the analysis allows the number of observed variables to be reduced from eleven to three while still conserving more than $60 \%$ of the inertia of the sum total of initial variables.

\footnotetext{
${ }^{7}$ In a general manner, the majority of papers using factor analysis aim to underline typologies of the cases and/or the variables studied. $N$ evertheless, it is possible to use factor analysis results to construct composite variables. Following Filmer and Prichett [1998], Sahn and Stifel [2000] or Berr et al. [2006], we implement factor analysis to determine a linear composite of the optimally-weighted observed variables in order to set up a sequence of non-observable synthetic variables measuring the degree of application of the second Washington consensus (W Cl).

${ }^{8}$ Technically a principle component can be defined as a linear combination of optimally-weighted observed variables.

${ }^{9}$ The principle results of PCA are reproduced in Annex 2. The complete results as well as the initial data are available from the authors themselves.
} 
Figure 1

The eleven variables projected onto factorial planes (F1, F2) and (F1, F3)
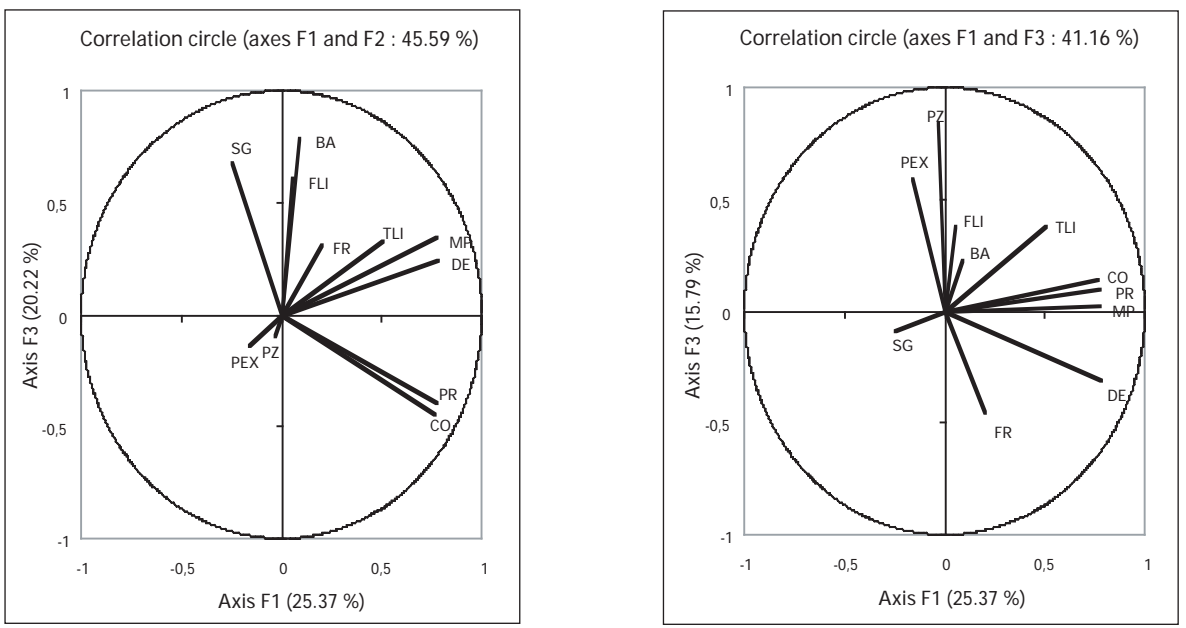

The correlation circles presented in figure 1 represent the projection of the eleven active variables onto the first two factorial planes. They account for the relations between variables and most importantly they characterize the three synthetic variables produced by the analysis. Examining the three axes together, we point out a particularly interesting phenomenon. Each one of the synthetic variables produced is principally correlated to a set of distinct initial variables. Thus, it is the variables relating to deregulation, property rights, monetary orthodoxy, competitiveness and to a lesser extent trade liberalization which contribute to more than $95 \%$ of the inertia of axis 1 . Within this set of measures applied collectively, the degrees of implementation of the measures relating to competitiveness, deregulation, monetary policy and property rights are strongly correlated. Tradeliberalization is for its part significantly correlated to the existence of monetary orthodoxy. In the same way, the variables relating to budgetary austerity, the size of government and financial liberalization capture almost two thirds of axis 2 inertia, and the variables relating to privatization and exports capture more than $60 \%$ of that of axis $3 .{ }^{10}$ Consequently, it appears that the advancement in 2003 of Latin A merican and Caribbean countries towards the objectives of IFIs is not established in a homogeneous manner for the eleven variables considered, as Correa [2002] has shown using a similar approach. O $\mathrm{n}$ the contrary, it includes three distinct and globally uncorrelated dimensions. Each one of these dimensions of the second Washington consensus assembles a set of

${ }^{10}$ The variable concerning fiscal reform partly contributes to the inertia of axis 3 , but its weak quality of representation leads us to abandon it for the remainder of the study. 
measures seemingly applied simultaneously in the observed countries. This means that among observed countries, some can be highly committed to the application of one of the dimensions that we have identified, without having made significant "efforts" to apply either one of the other two dimensions. Thus, even if the boundaries between the three dimensions of the second Washington consensus are not hermetic, as they represent different aspects of the same phenomenon, we suggest that axis 1 tends to combine the structural reforms favoring market regulation. Axis 2 concerns the size of government; the $\mathrm{FLI}$ variable representing a disengagement of the state in financial terms but also in the domain of exchange. Axis 3 represents the foreign dimension including privatization that often takes the form of takeovers by multinational firms that do not necessarily wish to invest in the local market.

We are now capable of assigning one score to each country to indicate that countries standing on each component. This component score is a linear composite of the optimally-weighted observed variables. As it stands, these scores do not make it possible to address the objectives of this study. In order to assess both the process of implementation of the second consensus and its effect on some economic and social indicators, it is important to operate a dynamic (or at the very least a static comparative) analysis of the changes in these different scores. Therefore, it is necessary to compute component scores for periods prior to 2003. ${ }^{11}$ On this basis, we can then measure the changes over time in the implementation of the different dimensions of the consensus. ${ }^{12}$ Thus, we can compare not only the degree of application of the consensus, but also the intensity of implementation of its constitutive measures to changes in some pertinent economic and social indicators. Table 1 offers a set of descriptive statistics concerning the degree of advancement and the changes over time in the three dimensions of the second Washington consensus. ${ }^{13}$

\footnotetext{
${ }^{11}$ The technique of factor analysis known as supplementary cases makes it possible to represent other cases (countries at periods prior to 2003) in the factor space corresponding to the principal variables (i.e. the 11 variables constitutive of consensus). Such supplementary cases will be the 23 Latin A merican and Caribbean countries observed in 1990, 1995 and 2000. They do not participate in the creation of factorial axes, but their position in the factor space corresponding to the principal variables can be computed, making it possible to assign a component score to each of these supplementary cases.

${ }^{12}$ This technique raises the question of the year of reference taken to analyze changes over time. Indeed, it would have been possible to perform PCA on the data for 1990 and to represent supplementary cases $(1995,2000$ and 2003) in the corresponding factor space. In this case, one observes the way things have evolved since 1990 and not how we have reached the situation of 2003. This phenomenon is susceptible of producing different results depending on the year taken as a reference point. Fortunately this is not the case here, as the changes observed using either one of the two reference points are very strongly and significantly correlated.

${ }^{13}$ We point out that the three synthetic variables produced by the analysis, as well as their change over time, reach Shapiro-Wilk and Anderson-Darling's tests of normality at the 1\% level.
} 


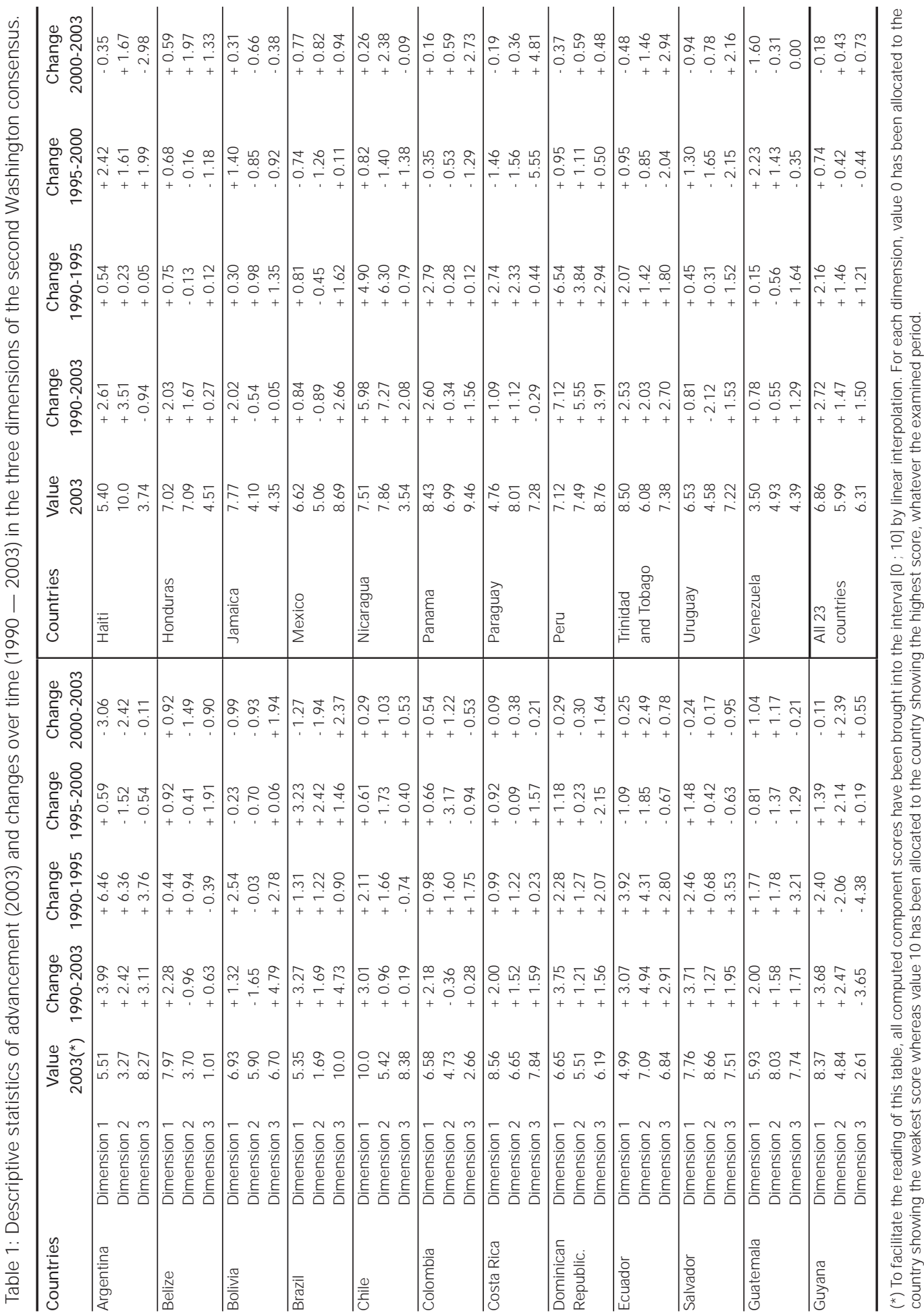


Table 1 shows several important elements. First of all, if one considers the degree of advancement of the different dimensions of IFI policies, it seems that in $2003 \mathrm{C}$ hile is the country the most clearly engaged in the measures constituting the first dimension. It is followed, in this category, by countries such as Costa Rica and Trinidad and Tobago. O $n$ the contrary, Venezuela appears to be the "bad pupil" in this dimension. With respect to the second dimension, Guatemala, $\mathrm{H}$ aiti and El Salvador are the most distinguished, as opposed to A rgentina and above all Brazil which is well below the mean values observed for this dimension. This observation demonstrates the difficulty IFIs have met in their effort to reduce state involvement in the larger developing countries that hope to play a significant role on the international scene. Finally, the third dimension distinguishes Brazil, Panama, Peru, M exico, Chile and A rgentina, as those for which the measures concerning privatization and exports seem to have been largely implemented. This is apparently not the case for Belize, Guyana, and Colombia.

W ith respect to the changes observed during the 1990-2003 period, there is clear evidence that the general rhythm of application of second consensus precepts was not homogeneous over time. ${ }^{14}$ W hereas during the 1990-1995 period, the implementation of the three dimensions is, on the whole, vigorous, the 19952000 period marks a strong decrease in the engagement of the 23 countries to apply IFI measures, so much that one can even observe a general tendency to backtrack from the application of the measures related to the last two dimensions. This would probably be explained by the financial crises that a certain number of Latin American countries experienced (M exico [1994-1995], Brazil [1998], Argentina [1995], Venezuela [1994-1995] for example), leading to problems of balance of payments (dimension 3) and an increasing distrust of state disengagement policies promoted by IFIs (dimension 2). Although the 2000-2003 period marks a relative return to the implementation of measures relating to the second and third dimensions, it also reveals a reversal concerning the application of measures relating to the first dimension. This confirms the increasingly strong hesitations toward the structural reforms held to be responsible for previous crises (Stiglitz [2000], [2002], Sanchez [2003], Davidson [2004], Lapeyre [2004], Berr and Combarnous [2005]). Examining the different cases, one can distinguish particular situations in certain countries. Bolivia, Paraguay, Uruguay and Venezuela regularly present very limited degrees of implementation, in some cases even backtracking from the different dimensions of the consensus. In spite of this, we notice a notew orthy engagement of Venezuela in the first two dimensions during the period 1995-2000. Peru and N icaragua, on the other hand, appear to be "good pupils", vigorously applying the three dimensions of IFI policies in the first period and then on a regular basis in the two following. Finally, Argentina and Brazil are distinguished by a highly vigorous application of IFI precepts (respectively during the periods 1990-1995 and 1995-2000) followed by a very

${ }^{14} \mathrm{H}$ ere we find a result already provided by Berr and Combarnous [2005]. 
clear reversal in most of the dimensions in the most recent period, confirming our conclusions relative to the effects of crises.

If one compares the changes over time in the degree of implementation of the different dimensions of the consensus for our 23 countries, two interesting elements appear. O $\mathrm{n}$ one hand, while the degrees of advancement observed in 2003 with respect to all three dimensions cannot be correlated, one does observe a strong positive and significant correlation between the variations of the first two dimensions during the period 1990-2003. In other words, this indicates that a strong degree of engagement in any one dimension of the consensus is not necessarily accompanied by a strong engagement in the other dimensions, but that policies relating to the first two dimensions are, generally speaking, jointly implemented. This is not the case for policies relating to the third dimension, which seem to be implemented independently from the two others. $\mathrm{O} n$ the other hand, the existence of a strong and significant negative correlation between the degree of engagement of countries in the first two dimensions in 1990 and their respective variations between 1990 and 2003 suggests a convergence of these two dimensions which does not appear for the third. The least advanced countries in 1990 being the most "dynamic" during the observed period tend to join the most advanced in the first two dimensions, but this convergence does not exist for the third dimension that is much more prone to factors of conjuncture influencing the level of the PEX variable.

Beyond this description of the way policies supported by IFIs were implemented during the 1990-2003 period, we must now assess their effectiveness concerning the objectives for which they were designed.

\section{THE EFFECTIVENESS OF THE SECOND WASHINGTON CONSENSUS IN QUESTION}

The policies advocated by IFIs have the primary objective of encouraging economic growth in the concerned countries in order to, among other things, allow them to reestablish the conditions of the repayment of their external debt. The effectiveness of these policies can be evaluated by examining the economic growth rate, but also changes in the debt of countries. Indeed, the policies inspired by the Washington consensus had initially been conceived as a response to the debt crisis that began in 1982. Consequently it will be necessary to examine if the countries most advanced in the various dimensions of the second consensus and/or those that have made the most important efforts in these different dimensions during the observed period benefit from a higher growth rate or positive changes concerning their indebtedness. ${ }^{15}$ It will al so be essential to consider

${ }^{15}$ The accent put on external debt is explained by the fact that the IFIs bet on the implementation of the Washington consensus to make the external debt sustainable whereas opponents of the Washington 
the impact of IFI policies on such essential variables as poverty and inequality. Indeed, beyond the hypothetical effectiveness of IFI policies, one must question their impact on the well being of the populations. The numerous critiques voiced against these policies, which have suggested their possible negative impact on the social dimension of development, incites such an interrogation.

Using our indicators, we are able to compare the degree of "realization" of the different dimensions of the consensus to what the IFIs consider to be likely indicators of the effectiveness of their policies. The variables that we use to characterize these different objectives are, respectively, the changes during the period in GDP, GDP per capita, the total amount of the external debt ${ }^{16}$ and debt service over $\mathrm{GNI}^{17} \mathrm{O}$ n the other hand, we also observe changes over time in inequality and poverty. As national measures concerning inequality and poverty are relatively rare and irregular, it is clearly not easy to establish precise estimates of their change during the observed period. This being so, it is possible to establish a rough estimate with respect to these changes, even if the years of observation only imperfectly coincide with the observed period. Thus, we have used several sources $^{18}$ to establish an estimate of the changes in inequality and poverty in a certain number of the countries in the sample during the period 1990-2003. These estimates make it possible to distinguish countries according to their "success" relative to these two points and to compare it to the implementation of the reforms.

The comparison of the changes in these variables and the implementation of the different dimensions of the consensus during the reviewed period can be conducted in different ways. The most rigorous approach would be to establish for each objective an econometric model in which our indicators would be exogenous variables among others. These models would allow us to assess the direction and the potential significance of the hypothetical relation between the implementation of the consensus and the achievement of its objectives, all things being equal. However the specification of such models largely exceeds the frame of this work. We therefore focus our attention on the search for potential direct links between the dimensions and objectives of the consensus. In order to do this, it is first possible to measure linear correlations betw een the application of different dimensions of the consensus and its objectives. It is how ever necessary to keep in

consensus consider this debt to be an instrument of domination which will not be able to be challenged by policies favoring creditors (Toussaint [2005]). We wish therefore to provide elements of response to this opposition.

${ }^{16}$ This variable was preferred to the weight of the external debt (external debt / GDP) which partly represents the influence of the change in GDP, already observed. We therefore ask if respecting the consensus allows for a better "control" of changes in the absolute value of the amount of the debt.

${ }^{17}$ All of this data comes from the World Bank [2005a].

${ }^{18}$ The Gini index that makes it possible to observe inequality comes from UN U-WIDER [2005] and the percentages of the population situated under the poverty line are taken from different editions of the H uman D evelopment Report from the UNDP and a set of reports on poverty in Latin A merica and the Caribbean from the World Bank that is available on its website. 
mind that the relatively small number of cases in the population could make these correlations particularly sensitive to the influence that extreme values held by one or several cases could have. To control for the potential bias related to the existence of such cases we can simultaneously transform our existing continuous variables into discrete variables with three modalities determined by the quantiles of their initial distribution. Then, we observe crosstabs that intersect for each period the modalities "weak variation" [minimum; $\left.p_{33}\right]$, "medium variation" $\left[p_{33} ; p_{66}\right]$ and "strong variation" [ $p_{66} ;$ maximum] in the observed dimension of the consensus and such and such an objective. ${ }^{19}$ The results are displayed in table 2 .

Table 2: Linear correlations between continuous variables and khi square tests between discrete variables, dimensions of the consensus and objectives;

23 Latin American and Caribbean countries, 1990-2003

\begin{tabular}{|c|c|c|c|c|}
\hline Objectives 1990-2003린 & & Dimension 1 & Dimension 2 & Dimension 3 \\
\hline \multirow[t]{2}{*}{ Variation in GDP } & Correlation & 0.261 & -0.071 & 0.042 \\
\hline & LR chi-square $^{3}$ & 2.438 & 2.438 & 6.534 \\
\hline \multirow[t]{2}{*}{ Variation in GDP per capita } & Correlation & 0.310 & -0.051 & -0.056 \\
\hline & LR chi-square & 5.210 & 0.712 & 6.028 \\
\hline \multirow{2}{*}{$\begin{array}{l}\text { Variation in the amount } \\
\text { of external debt }\end{array}$} & Correlation & -0.075 & -0.344 & -0.001 \\
\hline & LR chi-square & 2.187 & 8.917 & 0.461 \\
\hline \multirow{2}{*}{$\begin{array}{l}\text { Variation in the ratio } \\
\text { debt service / GNI }\end{array}$} & Correlation & 0.353 & 0.181 & 0.434 \\
\hline & LR chi-square & 5.349 & 4.669 & 4.669 \\
\hline \multirow[t]{2}{*}{ Variation in inequality $^{2}$} & Correlation & 0.032 & -0.099 & -0.276 \\
\hline & LR chi-square & 1.297 & 0.872 & 3.6458 \\
\hline \multirow[t]{2}{*}{ Variation in poverty ${ }^{2}$} & Correlation & -0.205 & -0.242 & -0.030 \\
\hline & LR chi-square & 6.882 & 2.075 & 3.913 \\
\hline
\end{tabular}

(1) The data in the table indicates the value of the correlations and the khi square tests between the degree of implementation of each one of the dimensions of the consensus during the period 1990-2003 and the changes over time in its objectives. The significant correlation or significant khi square at the $5 \%$ level are indicated in bold; (2) a positive variation in inequality or poverty corresponds to their decrease. The data for inequality only concerns 20 countries, and only 17 countries for poverty; (3) Because the number of observations is relatively limited during each period, Pearson's khi square tests raises a problem insofar as the normal approximation of the binomial distribution can be imprecise. It is therefore more appropriate here to utilize a khi square test based on maximum likelihood (likelihood ratio chi-square).

It appears that the implementation of the different dimensions of the second Washington consensus in Latin A merica and the Caribbean during the 1990-2003 period is not significantly related to the changes in its objectives. An engagement in the process of reforms is not accompanied by significantly stronger growth or

${ }^{19}$ This being done, we will do away with the bias related to the presence of extreme cases, while preserving the possibility of statistically testing the potential relation between the two variables using the khi square test of independence between variables. 
a significant decrease in poverty or inequality. The only thing we can notice is a certain statistical independence between the degree of advancement in the reforms and the "avowed" objectives of the consensus. ${ }^{20}$ The sole significant relation shows that the countries having most advanced in dimension 3 are also those for which the debt service/G N I ratio became worse. We also observe that if the period of analysis is broken into three sub periods (1990-1995, 1995-2000 and 2000-2003) and the same correlations are studied in each one of them ${ }_{1}{ }^{21}$ two elements appear: (1) a positive and significant correlation between the implementation of dimension 2 and the debt service during the first period, which supports what we have already established for dimension 3 over the whole period and (2) a positive and significant correlation between the implementation of the first dimension of the consensus and the variations in GDP and GDP per capita during the last period.

$\mathrm{O} n$ the basis of the significant results, we can formulate three commentaries. First of all it seems that increasingly outward oriented strategies and a growing external debt go hand in hand. Thus, contrary to the discourse of the IFIs, outwardoriented strategies do not make it possible to increase the currency reserves necessary for debt reimbursement. The PZ variable, constitutive of this dimension, even leads us to believe that privatization represents a loss of revenue for governments, ${ }^{22}$ thus contributing to an increase in the external debt. Second, we can legitimately attribute the correlation between government downsizing and the relative increase in the debt service between 1990 and 1995 to the concomitant liberalization of capital movement that provoked an inflow of capital, the increasing volatility of which partly caused the financial crises that affected Latin A merica in the second half of the 1990's. This interpretation is, moreover, validated by A restis [2004], Bresser-Pereira [2002], Bresser-Pereira and Varela [2004], Câmara N eto and Vernengo [2002], Carvalho [2002] and Stiglitz [2000, 2002]. Finally, the structural dimension is positively connected to GDP as well as GDP per capita only in the last sub-period. This result is surprising when one considers that growth in Latin A merica and the Caribbean had been very weak during this period. After being on average $3.7 \%$ in 2000 , it was $0.4 \%$ in $2001,-0.6 \%$ in 2002 before standing at $2 \%$ in 2003, which is clearly below international growth (ECLAC [2005]). It is thus possible that the correlation we have noticed follows principally from the fact that the countries experiencing the most difficulty during this period concomitantly slowed down the application of reforms. Indeed, the crisis of 2001 led Argentina to bring to a halt structural reforms while it was recording strong negative growth rates $(-4.4 \%$ in $2001,-10.8 \%$ in 2002), while Venezuela, which we have seen to have backtracked in theapplication of dimension

\footnotetext{
${ }^{20}$ In using the methodology of Lora [2001], M oreno-Brid et al. [2004] conclude that there is no relation between the degree of implementation of structural reforms and growth rate.

${ }^{21}$ The results of these additional measures are not detailed here.

${ }^{22}$ These losses can for example correspond with profits returning to foreign countries as privatization has largely profited multinational firms.
} 
1 (see table 1) between 2000 and 2003 also experienced such rates $(-8.9 \%$ in 2002 et $-9.7 \%$ in 2003) because of strikes and the coup d'état which paralyzed this country.

This being so, such an approach remains barely satisfactory with respect to our initial objective. Indeed, a separate analysis of each of the effects of the three distinguished dimensions prevents us from forming an overall judgment of the impact of the second consensus.

In order to judge the overall impact of the dimensions of this second consensus, it is necessary to establish a measure that makes it possible to distinguish those countries that have applied it with the most vigor. To do this, it is important to take into account simultaneously the degrees of engagement attained in 2003 in each dimension, but also, and most importantly, the variations in their implementation during our period of reference. It is on the basis of these six variables that the countries having best responded to the expectations of the international financial institutions must be distinguished. $\mathrm{O} n$ the other hand, it can be equally interesting to distinguish those countries that have made the most important efforts concerning the financial liberalization of their economies. This distinction is of particular importance insofar as the acceleration of financial liberalization constitutes the essence of the second Washington consensus.

Thus, we can clearly establish a set of five countries distinguished by their relatively vigorous engagement in all of the dimensions of the second Washington consensus during the period 1990-2003. ${ }^{23}$ The set includes: Argentina, Brazil, Ecuador, $\mathrm{N}$ icaragua and Peru. Concerning financial liberalization, we single out countries which have attained a high degree of financial liberalization in 2003 and which have also made significant efforts in this regard throughout the period of observation. This allows us to establish a list of 12 countries. ${ }^{24}$ It is then a question of seeing if these "good pupils" have benefited from a higher economic growth rate than the others, and/or if the situation relating to their debt has seen a relative improvement. $\mathrm{O}$ n the other hand, we also question whether or not they have made more significant advances concerning inequality and poverty. Table 3 measures the average change in the different objectives throughout the period 1990-2003 for all of the countries in the sample and whether or not they belong to the group of "good pupils" or the group of countries most engaged in the reforms related to financial liberalization.

\footnotetext{
${ }^{23}$ To do this, we have used the techniques of $\mathrm{K}$-means cluster analysis and hierarchical cluster analysis, applied to the 23 countries of the sample on the basis of the six variables considered.

${ }^{24}$ The variable considered here, produced by the IM F and taken from G wartney et al. [2005], measures the existence of 13 types of capital controls and restrictions to the access to international capital markets. We then distinguish on the basis of this variable and its evolution between 1990 and 2003, Bolivia, Costa Rica, Ecuador, El Salvador, Guatemala, H aiti, N icaragua, Panama, Paraguay, Peru, Trinidad and Tobago, and finally Uruguay.
} 
Table 3: Average values of the changes over time in variables characterizing the objectives of the second Washington consensus, 1990-2003

\begin{tabular}{lccccc}
\hline Objectives 1990-2003 & $\begin{array}{c}\text { «Good pupils» } \\
\text { 5 countries }\end{array}$ & $\begin{array}{c}\text { Other countries } \\
\text { 18 countries }\end{array}$ & $\begin{array}{c}\text { “Strong” FLI } \\
\text { 12 countries }\end{array}$ & $\begin{array}{c}\text { Other countries } \\
\text { 11 countries }\end{array}$ & $\begin{array}{c}\text { Total } \\
\text { 23 countries }\end{array}$ \\
\hline Variation in GDP & 0.445 & 0.538 & 0.483 & 0.556 & 0.518 \\
\hline Variation in GDP per capita & 0.165 & 0.230 & 0.172 & 0.265 & 0.216 \\
\hline $\begin{array}{l}\text { Variation in the amount } \\
\text { of external debt }\end{array}$ & 0.633 & 0.937 & 0.610 & 1.157 & 0.871 \\
\hline $\begin{array}{l}\text { Variation in ratio } \\
\text { debt senvice / GNI }\end{array}$ & 2.051 & 0.023 & 0.860 & 0.100 & 0.464 \\
\hline \begin{tabular}{l} 
Variation in inequality \\
\hline Variation in poverty
\end{tabular} & -5.2 & -2.9 & -5.6 & -1.3 & -3.5 \\
\hline
\end{tabular}

(1) Statistically significant mean differences (t-test for equality of means) appear in bold; (2) A positive variation in inequality or poverty corresponds to a decrease. The data for inequality concerns only 20 countries and only 17 countries for poverty of the 23 in the sample.

Let us first of all note that the small number of countries included in the sample is probably the reason for the few mean differences that are statistically significant at conventional levels. H owever, the coherence of the results obtained with the two partitions of the sample incites one to comment on some remarkable elements. Even if it is advisable to remain very prudent given the clear sensitivity of the analysis to the existence of extreme values for certain countries, we notice that the "good pupils" have not benefited from stronger economic growth than the others. It is the same for the countries having best responded to the objectives of financial liberalization. Concerning indebtedness, the "good pupils" have not achieved better results than the others during the period considered. They have even experienced a stronger increase than others regarding the debt service to GN I ratio, which confirms the conclusions already formulated. A Ithough this is not the case for the countries most engaged in financial liberalization, they nevertheless have not experienced a relative improvement in their debt situation. Finally, concerning poverty and inequality, we are struck by the fact that the "good pupils" on average see inequality worsen more than in other countries and poverty diminish less... Although the countries having best responded to the objectives of financial liberalization exhibit performances comparable to the others in terms of a decrease in poverty, they show, by contrast, a significantly worse result than the others with respect to inequality. The aggravation of this problem during the 1990-2003 period is much stronger there than elsewhere.

For more precision and to counterbalance the effects linked to the existence of extreme values, the results can be summed up in the two following figures. 
Figure 2

Changes over time in debt service and GDP per capita, 1990-2003

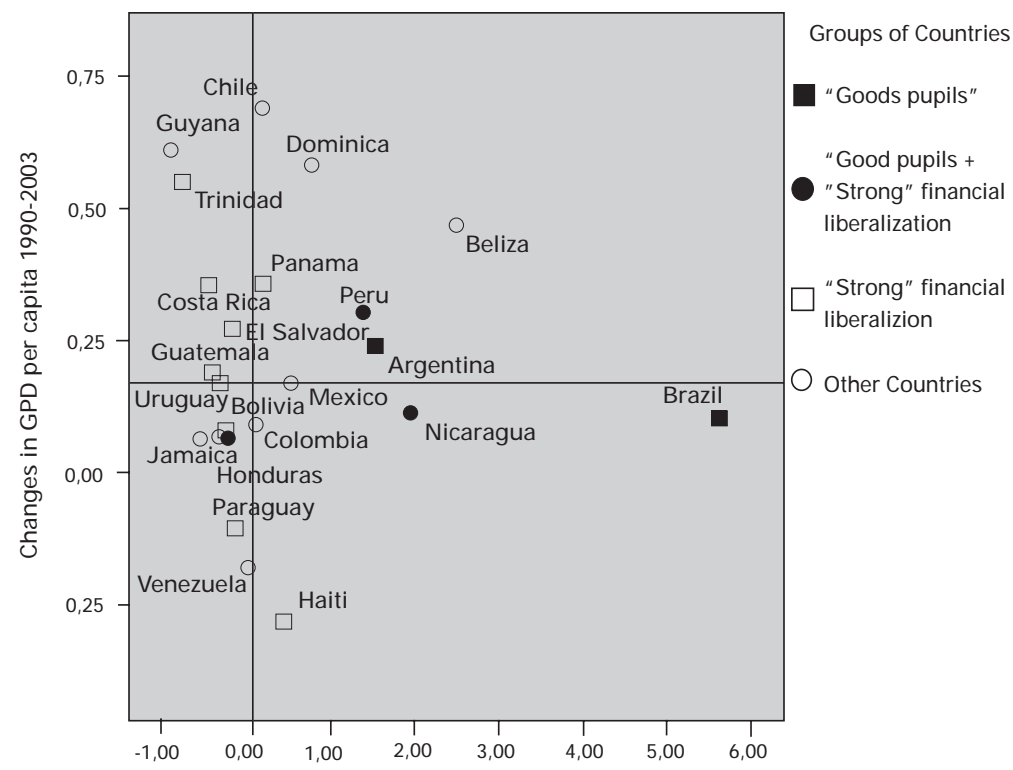

Changes in debt service to GNI ratio 1990-2003

Figure 3

Changes over time in inequality and poverty, 1990-2003

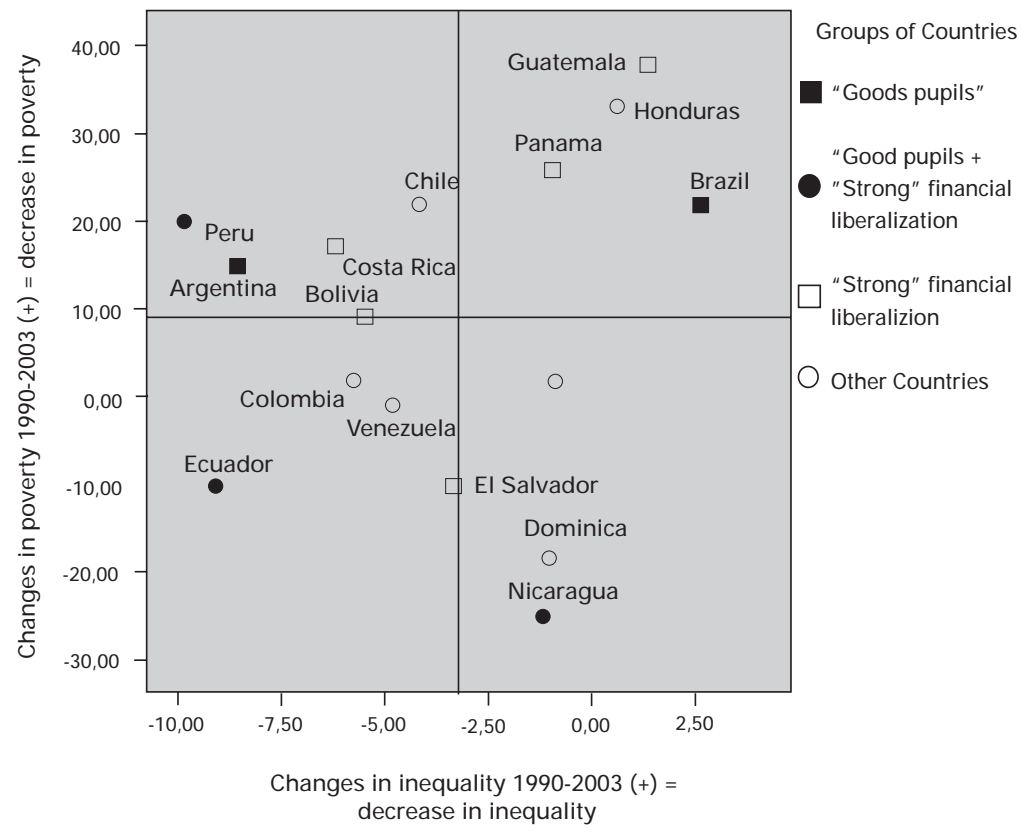


Figure 2 represents the relative "success" of countries in terms of growth and debt. It intersects the change in debt service to GN I ratio and that of GDP per capita during the 1990-2003 period on the first and second axes respectively. The relative success of countries is then assessed by their position in the four quarters established by the medians of the distributions of the two variables considered. However, the countries situated in the northwest quarter, which have experienced a controlled change over time in debt service and a relatively strong grow th of GDP per capita do not belong to the groups of countries having best applied the recommendations of international institutions. Figure 3, for its part, aims to assess the performance of countries in terms of poverty and inequality. To do this it intersects, according to the same principle as the preceding graph, the variation in inequality and that of poverty between 1990 and 2003, for the countries for which this data is available. With the exception of Brazil (which started with a situation of extreme inequality), the countries having most applied the recommendations of IFIs do not gain much in terms of the fight against poverty and inequality. The case of Ecuador might even be singled out as an example of (relative) "economic" success accompanied by disastrous social effects...

\section{CONCLUSION}

Rodrik [2006] emphasizes that no one believes anymore in the benefits of the Washington consensus. Since 1998, it has become clear for many that it creates more problems than it solves. According to Stiglitz [1998a], [1998b], we need to break from a narrow vision of development centered only on economic growth. The post consensus, as he liked to call it, was forced to recognize that development also involves an increase in the quality of life, health and education, that it must be sustainable, equitable, and democratic, and that it must preserve the environment. $M$ any have rallied to this larger view of development, which insists on the role of institutions and gives priority to the fight against poverty and inequality (Kuczynski and Williamson [2003], Birdsall and de la Torre [2001]). ${ }^{25}$ The international institutions themselves have integrated these changes into their discourse by promoting the M illennium D evelopment Goals.

Although the discourse has evolved, the practices neverthel ess remain strongly linked to a growth strategy oriented toward foreign savings that is denounced by Bresser-Pereira [2002]. O ur results confirm that such an approach weakens Latin A merican and Caribbean economies and holds them under the supervision of IFIs. The experience shows, however, as K eynes had already proclaimed in the 1930s, that development necessitates an approach centered on the domestic market. That being the case, the determination of the great powers, through the

${ }^{25}$ Williamson [2004] finally recognized the necessity of addressing the problem of inequality, but the methods he proposes are still largely inspired by the Washington consensus. 
G8 and IFIs, to continue to promote strategies largely based on the precepts of the (second) Washington consensus is surprising, except if one considers that they are acting only in their own interests and not in favor of the general good. The (wrongfully?) naive interrogation of Keynes concerning the fulfilment of his ideas - "A re the interests which they will thwart stronger and more obvious than those which they will serve?" (Keynes [1936], p. 383) - then takes on its full meaning and allows us to evaluate what needs to be done to definitively turn our backs on the Washington consensus.

\section{REFERENCES}

A restis, P., 2004, "Washington consensus and financial liberalization", J ournal of Post Keynesian Economics, vol. 27, $n^{\circ} 2$, p. 251-271.

Ben Gamra, S., Clévenot, M . 2006, “Libéralisation financièreet crises bancaires dans les pays émergents. La prégnance du rôle des institutions", CEPN Working paper n8, University of Paris XIII.

Berr, E., Combarnous, F., 2005. "Vingt ans d'application du consensus de Washington à l'épreuve des faits" , É conomie appliquée, vol. LVIII, n², p. 5-44.

Berr E., Combarnous F., Rougier E., 2005, "Too much consensus could be harmful: measuring the degree of implementation of the Washington consensus and its impact on economic growth", CED Working paper $n^{\circ} 116$, University of Bordeaux.

Birdsall, N ., de la Torre, A. 2001, Washington Contentious: Economic Policies for Social Equity in L atin A merica, Washington, Carnegie Endow ment for International Peace and Inter-A merican Dialogue.

Bresser-Pereira, L.C., 2002, "Brazil's Q uasi-Stagnation and the G rowth cum Foreign Savings Strategy", International J ournal of Political Economy, vol. 32, $n^{\circ} 4$, p. 76-102.

Bresser-Pereira, L.C., Varela, C., 2004, "The second Washington consensus and L atin A merica's quasistagnation", J ournal of Post Keynesian Economics, vol. 27, n² 2, p. 231-250.

Câmara N eto, A.F., Vernengo, M ., 2002, "Globalization, a Dangerous O bsession", International Journal of Political Economy, vol. 32, $n^{\circ} 4$, p. 4-21.

Carvalho, F.J.C., 2002, "Strengthening the Defenses of the Brazilian Economy A gainst External Vulnerability", International J ournal of Political Economy, vol. 32, n 4, p. 35-48.

Correa, R. 2002, "The Washington Consensus in Latin A merica: A Q uantitative Evaluation", N IP papers, http://www.grade.org.pe/eventos/nip_conference/private/C orrea-The\% 20 Washington $\% 20$ Consensus.pdf.

Davidson, P., 2004, "A Post Keynesian view of the Washington consensus and how to improve it", Journal of Post Keynesian Economics, vol. 27, n² 2, p. 207-230.

ECLAC. 2005, Statistical Yearbook for Latin A merica and the Caribbean, Santiago, Chile, United $\mathrm{N}$ ations.

Filmer, D., Pritchett, L. 1998, "Estimating wealth effects without expenditure data - or tears: an application to educational enrollments in states of India", World Bank, mimeo.

Gwartney, J., Lawson, R., Emerick, N . 2005, Economic Freedom of the World: 2005 Annual Report, The Fraser Institute, Vancouver, http://www.freethew orld.com.

Keynes, J.M ., 1936, The G eneral Theory of Employment, I nterest and M oney, The Collected Writings of John M aynard Keynes, vol. VII, 1973, London, The M acmillan Press.

Kuczynski, P., Williamson, J. (eds). 2003, A fter the Washington Consensus: R estarting G rowth and Reform in L atin America, Washington, Institute for International Economics.

Lapeyre, F. 2004, "Globalization and structural adjustment as a development tool", International Labour O ffice Working paper $n^{\circ} 31$, Geneva. 
Lora, E., 2001, "Structural reforms in Latin A merica: what has been reformed and how to measure it", I nter-A merican D evelopment Bank Working Paper $n^{\circ} 466$, Washington DC.

M oreno-Brid, J.C., Pérez Caldentey, E., Ruíz N ápoles, P. 2004, "The Washington consensus: a Latin A merican perspective fifteen years later", J ournal of Post K eynesian Economics, vol. 27, ${ }^{\circ} 2$, p. 345-365.

O campo, J.A. 2004, "Beyond the Washington consensus: what do we mean?", Journal of Post Keynesian Economics, vol. 27, n², p. 293-314.

Rodrik, D. 2004, "Rethinking Growth Policies in the Developing World", Luca d'Agliano Lecture in D evelopment, Turin, 8 octobre, http://ksghome.harvard.edu/ drodrik/Luca_d_Agliano_Lecture O ct 2004.pdf.

Rodrik, D., 2006, "Goodbye Washington Consensus, Hello Washington Confusion?", H arvard University, mimeo, http://ksghome.harvard.edu/ drodrik/L essons\% 20of\% 20the\% 201990s\% 20 review\% 20_JEL_.pdf.

Sahn, D., Stifel, D. 2000, "Poverty Comparisons O ver Time and Across Countries in Africa", World Development, vol. $28, n^{\circ} 12$.

Sanchez, O . 2003, "G lobalization as a D evelopment Strategy in Latin A merica ?" , World D evelopment, vol. $31, n^{\circ} 12$.

Stiglitz, J. 1998a, "M ore Instruments and Broader Goals : M oving toward the Post-Washington Consensus", WIDER Lecture, Helsinki, http://www.wider.unu.edu/publications/annuallectures/annual-lecture-1998.pdf.

Stiglitz, J. 1998b, "Towards a N ew Paradigm for Development : Strategies, Policies, and Processes", Prebisch Lecture, G enève, O ctober 19, http://siteresources.worldbank.org/N EW S/R esources/ prebisch98.pdf.

Stiglitz, J., 2000, "Capital M arket Liberalization, Economic Growth, and Instability", World D evelopment, vol. 28, n 6, p. 1075-1086.

Stiglitz, J., 2002, G lobalization and its D iscontents, N ew York, N orton.

Toussaint, E. 2005, Your M oney [or] Your Life. The Tyranny of G lobal Finance, Chicago, H aymarket Books.

UN D P. 2005, H uman Development Report, N ew York, UN DP.

UNU-WIDER. 2005, World Income Inequality D atabase, http://www.wider.unu.edu/wiid/wiid.htm.

Williamson, J. 1990, "W hat Washington means by policy reform", in Williamson J. (ed.), Latin A merica adjustment: how much has happened?, Washington, Institute for International Economics, http://www.iie.com/publications/papers/williamson1102-2.htm.

Williamson, J. 2000, "What Should the World Bank Think about the Washington Consensus?" , The World Bank Research O bserver, vol. 15, $n^{\circ} 2$, p. 251-264.

Williamson, J. 2004, "The strange history of the Washington consensus", J ournal of Post Keynesian Economics, vol. 27, n², p. 195-206.

World Bank, 2005a, World development indicators 2005, CD-RO M.

World Bank, 2005b, G lobal D evelopment Finance2005, CD -RO M.

\section{AN NEXES}

\section{Annex 1: M ethod for constructing the eleven constitutive variables of the second Washington consensus}

BA Variable: budgetary austerity

It combines the value of the budget balance over GDP with the value of debt service to $\mathrm{GN}$ I ratio (source: World Bank [2005b]). The two variables are standardized then brought into to the interval $[0 ; 10]$ (on all of the periods) by linear interpolation. The value of the budget balance is closer to 10 the higher it is, while the value of the debt 
service to $\mathrm{GN}$ I ratio is closer to 10 the more weak it is. The BA variable is the mean of the two variables above.

SG Variable: size of government

Composite variable synthesizing the share of public consumption in the total consumption and the share of transfers and subsidies in GDP. Source: G wartney et al. [2005], variables $1 A$ and $1 B$. The value even higher since the size of government in the economy is weak.

M P Variable: promotion of an orthodox monetary policy based on the liberalization of interest rates

It combines variables 5Aiv and 3 of G wartney et al. [2005] and thus simultaneously considers the methode of determination of interest rates, the orientation of the monetary policy, the level of real interest rates (5A iv), but also the inflation-growth differential, monetary instability and the inflation rate (3). The value of the variable is even higher since the monetary policy allows interest rates to be market-determined, durably positive, and since inflation and inflation differentials are weak and monetary stability predominates.

PEX Variable: promotion of exports

It combines the value of the balance of payments on current account over GDP with that of the anual percent growth of exports (source: World Bank [2005a]). Thetwo variables are standardized then brought into the interval $[0 ; 10]$ (on all of the periods) by linear interpolation; the value of current balance of payments is closer to 10 since it is high, and the value of exports grow th rate is closer to 10 since it is strong. The PEX variable is the mean of the two above variables.

TLI variable: trade liberalization

Composite variable synthesizing the level of tariff and non-tariff barriers to international exchange. Source: Gwartney et al. [2005], variables 4A and 4B. The value is even higher since the barriers are weak.

CO Variable: competitiveness of foreign direct investment

It combines the value of FDI net inflows as a percentage of GDP with an indicator of accessibility to the country for foreign investors (source: World Bank [2005a], G wartney et al. [2005], variable 4Ei). The two variables are standardized then brought into the interval $[0 ; 10]$ (on all of the periods) by linear interpolation. The value of the FDI variable is closer to 10 since it is high, and the value concerning the regulation of capital markets is even closer to 10 since it is flexible. The $\mathrm{CO}$ variable is the mean of the two variables above.

PZ variable: privatization

It considers the share of public investment in total investment, as w ell as the proportion of state-owned enterprises (source: G wartney et al. [2005], variable 1C). The value is even higher since the degree of privatisation is significant.

DE variable: deregulation

It synthesizes the degree of regulation of credit, labor and business (source: G wartney et al. [2005], variable 5). The value is even higher since these markets are deregulated.

FR variable: fiscal reform

It synthesizes taxes on income, profits and capital gains as a percentage of total taxes (source: World Bank [2005a]), top marginal income and payroll tax rates and income thresholds at wich they apply (source: G wartney et al. [2005], variable 1Dii). The two variables are standardized then brought into the interval $[0 ; 10]$ (on all of the periods) by linear interpolation; the value of the tax variable is even closer to 10 since it is weak, and that of tax rate is closer to 10 since it is weak and income thresholds are high. The FR variable is the mean of the two above variables.

PR variable: property rights 
The value is even higher since justice is independent, courts are impartial, intellectual property is protected, military interference in rule of law and the political process is weak, and integrity of the legal system is strong (source: Gwartney et al. [2005], variable 2).

FLI variable: financial liberalization

This variable measures the restrictions to engage in international capital markets, as well as the exchange control. Source: Gwartney et al. [2005], variable 4Eii. The variable is even higher since restrictions are weak.

\section{Annex 2: Principle PCA results}

Table 1: Simple correlations between $\mathrm{WCl}$ variables

\begin{tabular}{|c|c|c|c|c|c|c|c|c|c|c|c|}
\hline & 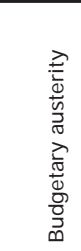 & 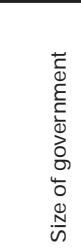 & 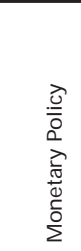 & 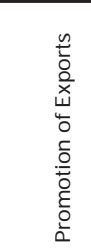 & 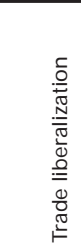 & 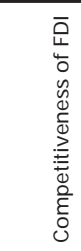 & 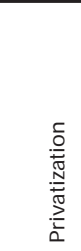 & 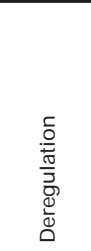 & 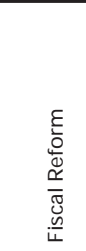 & $\begin{array}{l}\frac{y}{0} \\
\frac{0}{0} \\
\frac{0}{\alpha} \\
\frac{1}{2} \\
\frac{0}{0} \\
\frac{0}{2} \\
\frac{0}{2}\end{array}$ & 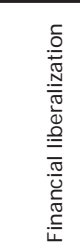 \\
\hline$\overline{\mathrm{BA}}$ & 1 & 0.300 & 0.254 & 0.104 & 0.241 & -0.244 & 0.063 & 0.287 & 0.145 & -0.194 & 0.508 \\
\hline SG & 0.300 & 1 & 0.157 & -0.164 & -0.008 & -0.430 & 0.033 & 0.033 & 0.080 & -0.428 & 0.210 \\
\hline MP & 0.254 & 0.157 & 1 & -0.067 & 0.495 & 0.456 & 0.045 & 0.587 & 0.337 & 0.333 & 0.071 \\
\hline PEX & 0.104 & -0.164 & -0.067 & 1 & 0.065 & 0.054 & 0.384 & -0.343 & 0.044 & -0.112 & -0.085 \\
\hline TLI & 0.241 & -0.008 & 0.495 & 0.065 & 1 & 0.251 & 0.114 & 0.173 & 0.089 & 0.202 & 0.305 \\
\hline $\mathrm{CO}$ & -0.244 & -0.430 & 0.456 & 0.054 & 0.251 & 1 & 0.119 & 0.379 & 0.003 & 0.680 & -0.175 \\
\hline $\mathrm{PZ}$ & 0.063 & 0.033 & 0.045 & 0.384 & 0.114 & 0.119 & 1 & -0.257 & -0.377 & 0.120 & 0.151 \\
\hline $\mathrm{DE}$ & 0.287 & 0.033 & 0.587 & -0.343 & 0.173 & 0.379 & -0.257 & 1 & 0.198 & 0.566 & 0.083 \\
\hline FR & 0.145 & 0.080 & 0.337 & 0.044 & 0.089 & 0.003 & -0.377 & 0.198 & 1 & -0.126 & -0.100 \\
\hline PR & -0.194 & -0.428 & 0.333 & -0.112 & 0.202 & 0.680 & 0.120 & 0.566 & -0.126 & 1 & -0.043 \\
\hline FLI & 0.508 & 0.210 & 0.071 & -0.085 & 0.305 & -0.175 & 0.151 & 0.083 & -0.100 & -0.043 & 1 \\
\hline
\end{tabular}

Note: bold values denote a significant correlation.

Table 2: Principal components loadings

\begin{tabular}{lccccccccccc}
\hline & PC1 & PC2 & PC3 & PC4 & PC5 & PC6 & PC7 & PC8 & PC9 & PC10 & PC11 \\
\hline BA & 0.057 & 0.527 & 0.173 & 0.024 & -0.244 & -0.450 & -0.323 & -0.298 & 0.187 & -0.322 & -0.309 \\
SG & -0.146 & 0.456 & -0.071 & -0.080 & 0.655 & 0.055 & 0.037 & 0.449 & -0.131 & -0.300 & -0.129 \\
MP & 0.462 & 0.233 & 0.016 & 0.211 & 0.344 & 0.088 & -0.010 & -0.123 & 0.288 & 0.633 & -0.248 \\
PEX & -0.097 & -0.092 & 0.448 & 0.578 & -0.091 & -0.314 & -0.157 & 0.514 & -0.132 & 0.174 & 0.058 \\
TLI & 0.305 & 0.219 & 0.286 & 0.133 & -0.171 & 0.698 & -0.339 & -0.028 & -0.268 & -0.193 & 0.139 \\
CO & 0.457 & -0.300 & 0.105 & 0.077 & 0.069 & 0.015 & 0.143 & 0.232 & 0.599 & -0.492 & 0.062 \\
PZ & -0.018 & -0.064 & 0.638 & -0.047 & 0.403 & -0.130 & 0.300 & -0.473 & -0.150 & -0.084 & 0.253 \\
DE & 0.467 & 0.163 & -0.236 & -0.182 & 0.039 & -0.389 & -0.176 & 0.093 & -0.212 & 0.066 & 0.652 \\
FR & 0.120 & 0.208 & -0.346 & 0.617 & -0.118 & -0.014 & 0.548 & -0.185 & -0.225 & -0.208 & 0.030 \\
PR & 0.466 & -0.268 & 0.075 & -0.233 & -0.046 & -0.167 & 0.120 & 0.111 & -0.533 & -0.068 & -0.553 \\
FLI & 0.031 & 0.410 & 0.289 & -0.348 & -0.413 & 0.067 & 0.547 & 0.310 & 0.120 & 0.191 & 0.070 \\
\hline Eigen values & 2.791 & 2.224 & 1.737 & 1.245 & 0.856 & 0.744 & 0.450 & 0.327 & 0.308 & 0.203 & 0.115 \\
\% of variance & 25.370 & 20.221 & 15.788 & 11.321 & 7.784 & 6.761 & 4.088 & 2.970 & 2.803 & 1.845 & 1.050 \\
Cumulative \% & 25.370 & 45.591 & 61.379 & 72.699 & 80.483 & 87.244 & 91.332 & 94.303 & 97.106 & 98.950 & 100.000
\end{tabular}

Note: bold values heavily contribute to PC's variation. 